\title{
The Construction of Gender: Judith Butler and Gender Performativity
}

\author{
$\mathrm{Li} \mathrm{He}$ \\ Foreign Language and Culture Department \\ North Sichuan Medical College \\ Nanchong, Sichuan, China
}

\begin{abstract}
Judith Butler is a famous American poststructuralism philosopher and an influential feminist pioneer. Her research covers a wide range of fields. This paper attempts to trace the development of Judith Butler's theory of gender in order to fully grasp the dynamic process of her thought. Her theory of "gender performativity" has deep influence on gender studies, contemporary political philosophy, ethics and other academic studies.
\end{abstract}

Keywords-Judith Butler; subjectivity; sex; gender; Performativity; gender contruction

\section{INTRODUCTION}

Judith Butler is the most influential feminist writer. Judith Butler was born on 24 February, 1956. In 1984, she received her Ph.D. in Philosophy from Yale University on the French Reception of Hegel. Now she is a professor in the Department of Rhetoric and Comparative Literature and is the Co-director of the Program of Critical Theory at the University of California, Berkeley. She founds a lot of theories in many fields. In her opinion, gender is constructed by the society. Human doesn't hold innate characteristic of it. From 1980s, Judith Butler has demonstrated the relation between sex and social gender. Since 1990s, Judith Butler's gender performativity theory swept the academic circles, has aroused great concern in western academic circles.

She reexamines the relationship between "sex" and "gender", "sex" and "gender" is totally different, and "gender" is constructed by the society. As a representative feminist theorist, she founded his theory in many fields, the research results contribute to the study of cultural theory.

This paper mainly focuses on Judith Butler's gender theory and its influence on the current society. Butler put forward the performativity theory, and it is a new theory in an open perspective. By now, she has made lot contributions to the fields of feminism, ethics, and queer theory and other academic fields.

\section{BASIS OF THEORETICAL RESEARCH}

\section{A. Reference to Beauvoir's "Sex" and "Gender"}

Judith Butler gets much from the famous theorist Simone de Beauvoir. Beauvoir's theory differentiate "sex" from "gender" and she clarifies gender is an aspect which the identity acquires step by step. Just as she mentioned in her book "One is not born, but rather becomes a woman." [1]

From her another book, The Second Sex, she reemphasizes that gender is constructed, but gender is changeable, meanwhile is controlled by our minds. We have to pay attention to the key word "become". It means everyone is under a cultural compulsion to become one. Of course here the compulsion is not from "sex", but from the circumstances. She mentions "body is a situation", "one" becomes a woman who is not needed female. Then the "gender" is constructed.

We know that it's very important for feminist to distinguish the difference between "sex" and "gender". Sex is thought to be invariant, distinct in the female body. In the context of culture, gender acquires the cultural meaning on the basis of body. Also gender makes body's acculturation in the variable modes. Moreover, if the difference is applied systematically, we can't clearly define if a given sex has any necessary consequence for being a given gender. From female's cultural interpretation, woman is being woman, and she is not necessary to be female, the female body is the arbitrary location of the gender "woman". And the body becomes the location of the constructions of gender. And we can conclude that "Being" female constructed genders.

\section{B. Butler develops the Conventional Thought}

Many years ago, the philosophers always have a question that the "Female" or "male" is being constructed by social culture or from the biological gene? Female or male, if it is the product of social culture, how her or his class, race, nationality, religion and sexuality, these social identities affect the construction of her or his gender identity in the process of "being"?

We accept that "Sex" is different from "gender", the feminist theorist Beauvoir explains that sex determines the certain social meanings for women's experience. Human's physiological and biological causality is sex. The focus is human beings - the lived experience contains body existence and also has the meanings of embodied existence. Butler emphasizes how we can necessarily get to know our sexed bodies, and we also try to understand how sexed bodies can be. She maintains the idea that our existence of abject bodies is completely contradictory, but the contradictory is on purpose. 
The post-colonial feminist Chandra Mohanty ever thought that we should treat "women" as a single and coherent group. She indicated that "sisterhood cannot be assumed on the basis of gender" [2]. In Butler's book Gender Trouble, she argues "women" are supposed to have a universal and unitary identity. For Butler, the inflexible label "woman" only serves to reinforce the very structure of power from which feminists sought to emancipate [3]. In feminist theory, "woman" is indeed a universal category.

Butler argues that "any effort to give universal or specific content to the category of women, presuming that that guarantee of solidarity is required in advance, will necessarily produce fact, and that 'identity' as a point of departure can never hold as the solidifying ground of a feminist political movement." [4] For Butler vision, conventional feminism welcomes the new forms of hierarchy and systems of exclusion.

\section{A concept of Subjectivity}

Butler ever says that "the subject is not determined by the rules through which it is generated because signification is not a founding act, but rather a regulated process of repetition." [3]

Women have met numbers of competitors and repressors to compete for the discursive power in the history, sometimes women have been called "subject". Butler reformulates the definition of "subject".

"Woman" exists as an ontological subject, she can not be divorced from the origin of situations, social history, and become a female in the process of being a woman, and she will be subject to the discipline of class, nationality, religion, sexuality and other types of social identity.

\section{For Butler, the subject is:}

“...designated as a linguistic category, a placeholder, a structure in formation ... The subject is the linguistic occasion for the individual to achieve and reproduce intelligibility, the linguistic condition of its existence and agency." [5]

It becomes more complicated as the subject is specified as "women". Some feminists claim that that "women" designates and reflects the material conditions of women's subordination and position within a system of patriarchy. The "subject" of "women" is in a linguistic situation. But a power should be exerted on the subject; subjection is nevertheless a power 'assumed by' the subject, an assumption that constitutes the instrument of that subject's becoming." [5] So it is obvious that the subjects need power to achieve their formation, at the same time they are exploited by the power. However, power is reliant on subjection; it is also built upon the subject formation. This is the relationship of power and subject. The behavior for social change shapes the power.

Language and thought sets the limitation. Butler states the difference between two kinds of the subjects. One subject is in linguistic field, the other is held as the individual in the space and time. In the world, the subject is as agent which is acting all the time. The former subject is rooted in discourse, specifically in the field of discourse of philosophy. The latter one is the individual subject, which can make some effect on the people and the objects around him or her. Just as the explanation above, a subject can be formed by power, and also the theoretical object, which can be looked as a linguistic place holder. Here is the rule for the subject formation. The subjects are tangible manifestations decided by the power. The "performance" of gender creates the subject;

\section{CONSTRUCTION OF SOCIAL GENDER}

Gender is different from sex, and it is the system, that social gender generally requires to constructs it. Gender also is a concept of the imagination which supports the foundations of patriarchal heterosexist hegemony.

Butler focuses on the concept of "subject". So she must explore the gender of main subject. But the research methods in spectrum science, the exploration must be from the result of the mechanism, discourse and culture In other words, human being, as a subject is defined first by society, culture, and discourse system, and what is defined here is man's gender. Even this defined process begins at birth.

\section{A. The Differences between Butler's Gender Construction and the Traditional Feminist Gender Construction}

Butler's gender construction and traditional feminist gender construction is essentially different, as Butler pointed out, for Beauvior, the gender is constructed, but her expression implied an actor, a "self-consider". The actor constructed the gender in a certain way. So, the construction can be a selection. Different from Beauvoir's existential view, Butler denied that there is a free subject behind gender identity will determines to choose will. This subject also can't determine what gender is. In her opinion, does not exist "I" before the gender performance, because that "I" is the repeated product. That is to say, that "I" holds the appearance of identity by its repeated actions. This means that subject is the performative construction, is constructed by repeatedly performing.

\section{B. The Performative Act and Gender}

Butler considers that a person's gender is the result of various discourse system mutual crisscross. Because this kind of interaction is always in the process of ongoing, a person's gender is "in process", as a main body can't be fixed. Here we must mention a controversial concept in her philosophy. That is performativity.

From the perspective of English speech, many people thinks that gender theory, butler's performativity is the same as performance, namely, gender is one's performance.In fact, the concept of performance assumes an anterior subject. A subject is in the performance. The most ordinary people think the Subject exists before the performance. But Butler wants to express a reverse logic, namely performance precedes the subject, and the subject is endowed with meaning in the process of performance. This fits into the interpretation of "gender" is a kind of process. And this means that we have hold the truth that "man" and "woman", "husband" and "wife", these gender identities don't exactly, solely exist, or we can sy they are not ontologically true.

"Performativity" has long time been looked as a dynamic concept. But Judith Butler really makes the "performativity" of the humanities and social sciences are "popular discourse". She gets much from Derrida. In the course of language and culture, she theoretically reinterprets and reexplains the meaning of 
"performativity". On the basis of "gender" and "body", she tries to construct a new theoretical system which has richer connotations. We have to admitted that if there is no the theory of "performativity", there is no Butler's "gender studies". And also we should admit that if there is no Butler, there is no present "performativity". In fact, the gendered body is performative. For Butler, the gendered body does not have ontological status, only by various performances to compose "reality". Behaviors and desires create the illusion of inner world, actually reinforce and regulate sexual norms within the heterosexual matrix. Actually Butler points out that "real" gender is actually illusory. A rule-limited discourse inserted with the pervasive and signifying and linguistic life can lead to culturally "intelligible" subjects. Identity, indeed for Butler, is a signifying practice.

She tries to explain that gender is socially constructed, and also be the appearance of natural things. For her, "such breakdown of gender binaries would then open up possibilities to the impossible, the illegible, the unrealizable, the unreal, and the unthinkable." [6] In fact, Butler argues the "reality" of gender is changeable, variable reality. Then, how to recodified gender, represent the relationship with the "power".

In Butler's opinion, gender is performative. Although tt is difficult for us to point out exactly what performativity is, Butler admits the power of it. However, she narrows the definition of performativity. It is "not a singular act, but a repetition and a ritual", so it leaves us more space for a flowing and flexible identity. Here the theory is that performativity is different from performance. Performativity should be reunderstood by more "limited notion of resignification." Ever Butler says "no doer behind the deed" in an interview. The doer becomes formed from the doing. Likes Foucault's notion of discourse, Butler's performativity is similar to "both of them are not voluntary, often we are unconsciously and actively aware of our own actions", as we "become subjects from our performances and the performances of others towards us" [5].

In Butler's view, the gender is not innate, or what we have, but depends on our behavior. In order to avoid identity type immobilization, she thinks the exact meaning of identity should let forever in the fuzzy state, and then puts forward the concept of "gender performativity". In her theory, there is no prototype of gender performance can be imitated; it is not a true imitation of sex, but to imitate an ideal mode. This mode is the selfdesign and imagination, does not exist in any place, never fixed, only continually repeated in every gender performance.

Performativity is fundamental features of gender. The origin of gender is performance rather than the body. Cultural norms continue constantly updating, revising and consolidating. So the "body" slowly gets "gender". In the course of history and foreign cultural symbols in sedimentary accumulation, the body's gender identity form. Gender is a symbolic narrative effect, is a set of recognition of mental symbols imposed on body. [7]

\section{Judith Butler's Gender Performativity}

The Gender Trouble was published in 1990, is considered as a masterpiece of Judith Butler. It has enormous influence on the modern gender theory. Butler is greatly influenced by post- structuralism and structuralism. At the beginning of Gender Trouble, She says, "Ontology is, thus, not a foundation, but a normative injunction that operates insidiously by installing itself into political discourse as its necessary ground." [3] She thinks that "the rules that govern intelligible identity ... rules that are partially structured along matrices of gender and hierarchy and compulsory heterosexuality, operate through repetition." [3]

Early in her books, Butler invites the theory of performances to discuss how gender is constructed through the performances of the body. To her, the body is not only materiality, but also is the continuous materiality of identity. A man has a body, but more important, he "does" his own body. Depending on the repeated performances, the body becomes a historical existence. The physical actions give individual's identity which contains gender, race, and others.

In Gender Trouble, Butler further says that:

"If gender is an object which a person want to be (but never fully realized), then gender is a process or action. Gender should not be used as a noun, an existence of essence, or a static cultural label. It should be considered as a repeated behavior." [3]

The behavior of gender must follow certain norms. So it needs to go through the process of normalization, and repeats in a limited range of duplication and forms. Butler redefined the meaning of gender. Gender is not inherent, but is produced by the pressure of the discipline. This pressure regulates our performance.

The "performance", is not a single action, but a repetition, as: "... performative acts must be reproduced to become efficacious." The performance of gender according to Butler is not voluntary; it is compelled due to the regulatory regime of compulsory heterosexuality. This regime constructs the cultural genders. Performativity is one of the key words in the field of Humanities and Social Sciences. "Discrete genders are part of what 'humanizes' individuals within contemporary culture" [3] Butler pays close attention to the problem of gender trouble and her research is relevant to the contemporary society.

Butler's Performativity Theory gives a far-reaching impact on women and gender studies, and gives influences on the entire field of cultural studies.

\section{The Construction of Judith Butler's Gender Identity}

According to Butler's research, "gender" is a term which is created by Western feminist scholars and activists in twentieth Century 70, popularized and used today. The earliest usage can be traced back to Gaye Rubin.

The sexed body ever was established to be a "natural" and unquestioned "fact". It is essential for constructions of gender and sexuality. As to Butler, it is the basis of the construction of natural binary sex, binary gender and "compulsory heterosexuality". It is constructed naturally. [3] She argues: "...If the immutable character of sex is contested, perhaps this construct called "sex" was as culturally constructed as gender; indeed, perhaps it was always already gender, with the consequence that the distinction between sex and gender turns out to be no distinction at all. [3] The meaning of this sentence 
is that identity is constructed by culture, and the hidden meaning is that although the physiological attributes of human beings are established, but the gender identity can be changed, is completely open.

Gender for Butler doesn't imply an effect of an oppressive social power structure. Gender ought to be conceived as the cultural inscription of meaning on a pre-given sex. The notion of gender needs to be reconstructed by performativity. She stressed that gender is performative in the book Gender Trouble. There is no a preexistent identity as a measure based on the attribute. It is not fixed, stable identity, but performs depending on the time and the temporary liquidity of the places. Influenced by Derrida and Foucault, at the beginning of Gender Trouble, Judith Butler questions the originality of "identity". Like Foucault, she thinks that the rules that govern intelligible identity, rules that are partially structured along matrices of gender and hierarchy and compulsory heterosexuality, operate through repetition. According to Judith Butler, identity is looked as a signifying practice, and subject is the resulting effects of a rule-bound discourse. Butler locates the gendered, sexed, desiring subjects within the "regulative discourse". This term is borrowed from Foucault's Discipline and Punish. Regulative discourse embodies the appearance of the "core" gender, sex and sexuality. Besides, regulative discourse decides the possibilities of sex, gender and sexuality in advance. The behavior of gender must obey the norms, needs the process of normalization, and repeats in a limited range of duplication and forms.

Gender identity, its construction needs the actions of body. The identity is not only material "existence", but also rewritten in the cultural field. Gender Performativity completely overturned the heterosexual hegemony of gender identity model. [8] That is we are born as man or woman, born with biological characteristics of male or female. By repression of the desire for mother, we gradually obtain the culture gender identities - man or woman.

\section{CONCLUSION}

Judith Butler thinks that gender is constructed by the society, and it is not the innate characteristic of human beings. Since 1980s, Judith Butler has committed to rethink the relation between sex and social gender.

We can find that Butler works on the basis of Beauvoir's gender analysis. In the past, gender study ignored the body of the subject. But for Butler, the body, the subject implies mortality, vulnerability, and agency. Its physical presence reveals us to notice the relation with the society. Here "doing" and "being done to" become equivocal. The subject has its invariably public dimension and gender is constituted as a social phenomenon in the public atmosphere. The book Gender Trouble raised the heated discussion about gender performativity. Although everyone pass different judgments, Butler did become the representative of postmodernism, also became the founder of queer theory. Her theory has played a role on the identity politics and brings impact on traditional gender theory. Queer theory is based on gender. The theory is so hot around the world now, and it reveals the social construction. Butler's personal queer identity lets her have profound insights for the limitations of feminism.
As a feminist theorist, the core of Butler's thought is to make a deep analysis of the formation of the subject, because the feminist theory is just to reconstruct the subjectivity of women. She is acclaimed as a great thinker in the contemporary academic circle. Through different writings, Judith Butler was in response to various criticisms to enrich her own theories, strengthen the subversion of gender performativity theory. At the same time, in her process of continuous writing, she modifies her theories. So inevitably her thoughts will continue giving off enduring charm. The further research and criticism in her studying area become more urgent and necessary.

\section{REFERENCES}

[1] Simone de Beauvoir, H·M.Parshley interpreted, The Second Sex, Vintage, 1989, pp301.

[2] Mohanty, C. Under Western Eyes: Feminist Scholarship and Colonial Discourses. Feminism Review , 1988, 30(3), pp65.

[3] Butler, Judith, Gender Trouble: Feminism and the Subversion of Identity. New York and London: Routledge, 1990, pp5, 6, 7, 43, 145, 163,177, 185,189 .

[4] Butler, Judith, "Contingent foundations: Feminism and the question of postmodernism". In Butler, J., \& Scott, J. (eds.) Feminist Theorize the Political, London, Routledge, 1992, pp15.

[5] Butler, Judith, The Psychic Life of Power: Theories in Subjection. Stanford: Stanford University Press, 1997, pp10-11, 99.

[6] Butler, Judith, Bodies That Matter: On the Discursive Limits Of Sex. New York and London: Routledge. 1993, pp3.

[7] He Li, A Study on Judith Butler's Social Gender, Master's thesis, unpublished, University of Electronic Science and Technology of China, 2012, pp26-27.

[8] Du Lanlan, Development of Judith Butler's Theory of Gender, Collection of Women's Studies, Nov.2010, No.6 Ser.No.102, pp67. 